UDC 619: 616. 993.6: 636.7/8

DOI https://doi.org/10.32851/2226-0099.2019.109-2.20

\title{
DISTRIBUTION OF BABESIOSIS OF DOGS, DEPENDING ON THEIR AGE, PEDIGREE SENSITIVENESS AND SEX
}

\author{
Soloviova L.M. - C. of Vet. Sciences, Associate Professor, \\ Associate Professor of the Department of Parasitology and Pharmacology, \\ Bila Tserkva National Agrarian University \\ Erohina O.M. - Lecturer, Bila Tserkva Technological and Economic College \\ of the Bila Tserkva National Agrarian University \\ Peresunko O.D. - Lecturer, Bila Tserkva Technological and Economic College \\ of the Bila Tserkva National Agrarian University \\ Chovgun A.M. - Lecturer, Bila Tserkva Technological and Economic College \\ of the Bila Tserkva National Agrarian University
}

For today this invasion has extraordinarily wide distribution among dogs on all continents of Earth, in different natural and climatic zones. The dogs with babesiosis not only lose health and bring moral and material losses to the owners, but also become the transmitters of chronic pathologies, and in case of ill-timed diagnostics and treatment perish.

According to the results of the epizootiological studies it has been examined the spread of dogs'babesiosis in Bila Tserkva of the Kiev region.

The study found that in Bila Tserkva were registered 8 contagious pathologies of animals. Among parasitic diseases of private veterinary hospital PE "Romanenko" of Bila Tserkva it was mostly registered babesiosis, demodecosis, flea infestation (ktenotsefalidoz), otodektoz and helminth infections; to a lesser extent it was registered scabies (sarcoptic mange), dirofilariosis and toxoplasmosis. The degree of damage by babesiosis of dogs in the total incidence of diseases, caused by parasitic protozoa, in Bila Tserkva has amounted to $99.4 \%$.

While studying dogs' babesiosis it was revealed that the peak of the disease occurs in May and reaches at the average 30\% of the animals examined. In September-October about 14\% of the animals, were sick due to the biological activity of the ixodic ticks.

For the last 2 years we noticed that babesiosis sick dogs are of different age groups. Most of all dogs 1-3 years of age suffer from babesiosis. More susceptible are male dogs. Males were 1.22 times more likely to be infected with babesiosis than females. Regarding the sex of dogs over the past 2 years among patients on parasitic diseases males accounted for 54.6 percent, and females of $45.4 \%$.

With regard to the sensitivity of the breed, the greatest number of dogs with babesiosis is found among German Shepherds, Cocker Spaniels, Syaffterriers and outbred.

Key words: dogs, babesiosis, age, sex, breed, Babesia.

Соловйова Л.М., Срохіна О.М., Пересунько О.Д., Човгун А.М. Розповсюджсення бабезіозу собак залежно від їх віку, порідної чутливості та статі

Сьогодні бабезіоз надзвичайно широко розповсюджений серед собак на усіх континентах земної кулі й у різних природно-кліматичних зонах. Хворі на бабезіоз собаки не лише втрачають здоров'я та завдають моральних $і$ матеріальних збитків своїм господарям, а і стають носіями хронічних патологій, у разі ж несвоєчасної діагностики та лікування гинуть.

За результатами епізоотологічних досліджень вивчено поширення бабезіозу собак y м. Біла Церква Київської області.

Проведеними дослідженнями встановлено, щуо ум. Біла Церква реєструвалося 8 заразних патологій тварин. Серед паразитарних захворювань приватної ветеринарної лікарні ПП «Романенко» найчастіше реєстрували бабезіоз, демодекоз, блочину інвазію (ктеноиефалідоз), отодектоз і гельмінтози; меншою мірою-саркоптоз, дирофіляріоз і токсоплазмоз. Ступінь ураження бабезіозом собак у загальній захворюваності на хвороби, викликані паразитичними найпростішими, в м. Біла Церква становила 99,4\%.

При вивченні захворювання собак на бабезіоз виявили, щзо пік захворювання припадає на травень і досягає в середньому 30\% від кількості обстежених тварин. У вересні-жовтні 
хворіло близько 14\% тварин, щзо пов'язано з біологічною активністю іксодових кліщів. За останні 2 роки ми відзначили, щзо на бабезіоз хворіють собаки різних вікових груп. Найчастіше хворіють собаки 1-3-річного віку. Більш сприйнятливі особини чоловічої статі собак. Самиі уражувалися збудником бабезіозу в 1,22 рази частіме порівняно із самками. Щодо статі собак, за останні 2 роки серед хворих на паразитарні захворювання самці складали 54,6\%, а самки - 45,4\%.

Щодо порідної чутливості, то найбільша кількість хворих на бабезіоз собак зустрічається серед німецьких вівчарок, кокер-спанієлів, стафордширських тер 'єрів і безпорідних.

Ключові слова: собаки, бабезіоз, вік, стать, порода, бабезї.

Formulation of the problem. Babesiosis as the disease of dogs is known from the end of XVIII century. In Ukraine the given protozoasis was educed at the beginning of XIX century. For today this invasion has extraordinarily wide distribution among dogs on all continents of Earth, in different natural and climatic zones. The dogs with babesiosis not only lose health and bring moral and material losses to the owners, but also become the transmitters of chronic pathologies, and in case of ill-timed diagnostics and treatment perish [2, p. 8; 7, p. 88; 8, p. 208; 9, p. 708]. Therefore, the study of babesiosis of dogs, including the research of epizootic situation is timely.

Analysis of recent research and publications. At the study of epizootic situation in relation to babesiosis of dogs in Kharkiv it is set that the peak of disease incedence is in May $(56.6 \%)$ and a second peak is in October $(13.1 \%)$ [3, p. 25]. The territory of Zhytomyr city is unfavourable in relation to babesiosis, a part of that from all parasitogenic illnesses presents $61.2 \%$ [6, p. 260]. Radiation contamination of biological transmitters of a causative agent - claws of sort of Dermacentor - influences on the increase of distribution of babesiosis in the zone of Polissia [1, p. 39].

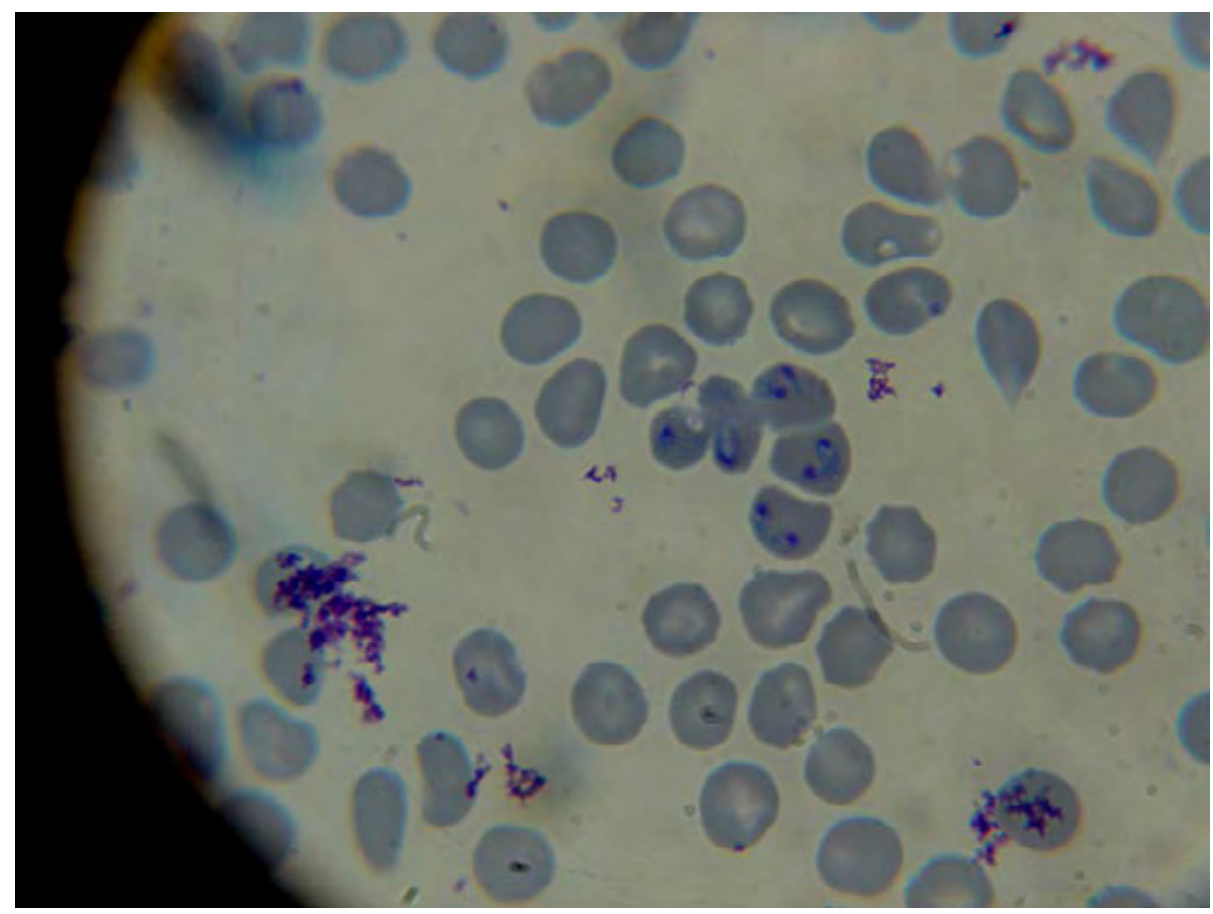

Pic. 1. Babesia in the field of view of the microscope (Coll. 10h100) in blood smears of ill researched dogs 
At the study of epizootological display of babesiosis of dogs it is educed in Kyiv, that among helminthiases $42-47 \%$ is babesiosis. Mostly, babesios was registered in April-May (from $18.99 \%$ to $21.52 \%$ and September-October (12.03-15.82\%). In relation to an age-old display, more often on babesiosis dogs were ill in age $1-3(23.42 \%)$. $55.3 \%$ were males and $44.7 \%$ were females. In Donetsk in summer months there was high enough extensiveness of babesiosic invasion (in July - 7.7\%, in August $8.6 \%$ ). Mostly affected by the causative agent of babesiosis were dogs breeds poodle, Doberman Pinscher (8.6\%), Chow, Spaniel, and Airedale Terrier (7.7\%), collie, boxer $(6.8 \%)[4$, p. $12 ; 5$, p. 10$]$.

The purpose of the study is this work was to study the distribution of babesiosis in a private veterinary hospital PE "Romanenko", the city of Bila Tserkva.

To achieve the goals were set the following tasks: a) according to the accounting documentation of private animal hospitals PE "Romanenko" the city Bila Tserkva, to identify patients with babesiosis in a common contagious disease of dogs; b) to study the susceptibility of dogs to the pathogen of babesiosis, depending on the age, sex and breed.

The material for the study was 370 dogs ill with babesiosis - patients of private veterinary hospital PE "Romanenko" the city of Bila Tserkva, and the blood from them. For the diagnosis of babesiosis were taken the first drop of blood from the tip of the dog's ear on a glass slide, a smear was made, fixed and stained by Romanovsky-GSI. Babesia were in the red blood cells of the affected dogs (Pic. 1).

Main results of the study. According to the "Journal of registration of sick animals" for the year 2013, the owners of 765 dogs asked for help. Of these, 180 patients had a parasitic disease, that is $23.53 \%$. In the course of 2014, 740 dogs became patients at private animal hospitals PE "Romanenko" city of Bila Tserkva, of which 190 were dogs with parasitic etiology of diseases, which amounted $25,68 \%$. That is on average for 2 years parasitic diseases were found in $24.6 \%$ of dogs.

The study found that in Bila Tserkva were registered 8 contagious pathologies of animals. The largest share (42.7\%) were babesiosis, $25.13 \%$ - demodecosis, $16.22 \%$ - ctenocephalides, $7.3 \%$ of otodectosis and $6.76 \%$ - helmints disease. The number of patients with the sarcoptic mange was $0.81 \%$, with dirofilaria is $0.81 \%$ and $0.27 \%$ for toxoplasmosis. Among helminthoses of dogs most often was recorded diplos, toxocariasis and trichuris. The degree of damage by babesiosis of dogs in the total incidence of diseases, caused by parasitic protozoa, in Bila Tserkva has amounted to $99.4 \%$ (table. 1).

Table 1

The incidence of dogs on parasitic diseases

\begin{tabular}{|l|c|c|c|c|}
\hline \multicolumn{1}{|c|}{ Name of disease } & $\mathbf{2 0 1 3}$ & $\mathbf{2 0 1 4}$ & In total & Percent ratio \\
\hline Babesiosis & 78 & 80 & 158 & $42.7 \%$ \\
Demodicosis & 48 & 45 & 93 & $25.13 \%$ \\
Ctenocephalides & 25 & 35 & 60 & $16.22 \%$ \\
Otodectosis & 15 & 12 & 27 & $7.3 \%$ \\
The Sarcoptic Mange & 10 & 15 & 25 & $6.76 \%$ \\
Helminthiasis & 2 & 1 & 3 & $0.81 \%$ \\
Dirofilaria & 2 & 1 & 3 & $0.81 \%$ \\
Toxoplasmosis & - & 1 & 1 & $0.27 \%$ \\
\hline In total & 180 & 190 & 370 & 100 \\
\hline
\end{tabular}

In the evaluation of the epizootic situation in Bila Tserkva for the last 2 years we noticed that babesiosis sick dogs are of different age groups (table. 2). 
Table 2

Age dynamics of the spread of babesiosis of dogs

\begin{tabular}{|l|c|c|}
\hline \multicolumn{1}{|c|}{ Age of dogs } & Number of dogs & Number of dogs percentage \\
\hline 2-6 months & 30 & 18.98 \\
\hline 6 months - 1 year & 32 & 20.25 \\
\hline 1-3 years & 37 & 23.42 \\
\hline 3-5 years & 34 & 21.53 \\
\hline Older than 6 years & 25 & 15.82 \\
\hline In total & 158 & 100 \\
\hline
\end{tabular}

Of the 158 patients dogs 37 were aged $1-3$ years $(23.42 \%), 34-3-5$ years $(21.53 \%)$, 32 from 6 months to 1 year $(20.25 \%), 30$ dogs $2-6$ months $(18.98 \%)$ and 25 were older than 5 years $(15.82 \%)$. So, most of babesiosis sick dogs $1-3$ years of age.

Regarding the sex of dogs over the past 2 years among patients on parasitic diseases males accounted for $54.6 \%$ (202 dogs), and females of 45.4\% (168 dogs). More often among males was also recorded babesiosis. In General, for 2 years babesiosis was hurting 87 males (55\%) and 71 female (45\%) (table. 3 ).

In 2013 , babesiosis was amazed by 43 males and 35 females that were, respectively, $55.13 \%$ and $44.87 \%$. In 2014, these figures were, respectively, $44(55 \%)$ and $36(45 \%)$. The presence of a larger number of males among patients with babesiosis is related to the fact that dogs male population is bigger than female (table 3 ).

We also noticed that dogs of different breeds are not equally susceptible to the pathogen of babesiosis. Thus, the most susceptible to the disease turned out to be dog breeds German shepherd (23.42\%), Cocker Spaniel (17.72\%), Staffordshire Terrier

Table 3

Sexual dynamics of the spread of babesiosis of dogs

\begin{tabular}{|l|c|c|c|c|}
\hline Sex of dogs & $\begin{array}{c}\text { Number of dogs } \\
\text { in 2013 }\end{array}$ & $\begin{array}{c}\text { Number of dogs } \\
\text { in 2014 }\end{array}$ & In total & $\begin{array}{c}\text { Number of dogs } \\
\text { percentage }\end{array}$ \\
\hline Males & 43 & 44 & 87 & 55 \\
\hline Females & 35 & 36 & 71 & 45 \\
\hline In total & 78 & 80 & 158 & 100 \\
\hline
\end{tabular}

Pedigree peculiarity of the distribution of babesiosis in dogs

\begin{tabular}{|l|c|c|}
\hline \multicolumn{1}{|c|}{ Breed } & Number of dogs & Number of dogs percentage \\
\hline German shepherd & 37 & 23.42 \\
\hline Cocker Spaniel & 28 & 17.72 \\
\hline Staffordshire Terrier & 21 & 13.29 \\
\hline Mongrel & 19 & 12.03 \\
\hline Assize & 16 & 10.13 \\
\hline Eskimo dog & 12 & 7.59 \\
\hline Pekinese & 10 & 6.33 \\
\hline Rottweiler & 8 & 5.06 \\
\hline Other breeds & 7 & 4.43 \\
\hline In total & 158 & 100 \\
\hline
\end{tabular}


(13.29\%), mongrel (12.03\%), assize (10.13\%), eskimo dog (7.59\%), Pekinnese (6.33\%), Rottweiler (5.06\%). A number of other breeds made up $4.43 \%$ (table. 4 ).

In dogs with babesiosis, 2 peaks of incidence were recorded: the first - in April May; the second - in September - October, which, in our opinion, is related to the cycle of tick development and their new generation (Fig. 2).

Thus, in March the number of patients with babesiosis was 5.7\% ( 9 dogs), in April $21.52 \%$ (34 dogs), in May - 18.99\% (30 dogs). 6.33\% (10 dogs) became ill in June, $3.16 \%$ (5 dogs) in July, 7.59\% (12 dogs) in August. In September, 12.03\% (19 dogs) were admitted, $15.82 \%$ (25 dogs) in October and 8.86\% (14 dogs) in November. In December, January and February, patients with babesiosis were not registered at the private veterinary hospital of Romanenko, Bila Tserkva.

Thus, it was found that the epizootic process of babesiosis invasion of dogs in Bila Tserkva has certain features and is characterized by a pronounced seasonality.

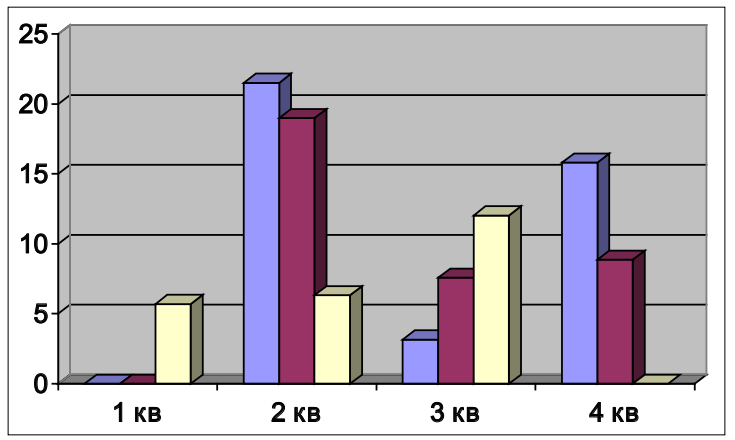

Pic. 2. Annual dynamics of babesiosis invasion of dogs, \%

Conclusions. The highest incidence of babesiosis infestation of dogs was detected in May, when nearly $20 \%$ of the dogs examined had the disease, and September-October (about $14 \%$ of the animals were sick) due to the biological activity of the ixodic ticks.

Dogs between the ages of 1 and 5 were most susceptible to the disease.

Males were 1.22 times more likely to be infected with babesiosis than females. More susceptible to the causative agent of babesiosis were dogs of the German Shepherd, Cocker Spaniel, Staffordshire Terrier, and allied.

Application of effective treatment regimens for dogs for babesiosis and hematological and biochemical studies of blood and serum from sick dogs.

\section{REFERENCES:}

1. Дубова О., Сорока Н. Еколого-епізоотичні особливості біотопів іксодових кліщів-переносників бабезіозу собак в умовах міста. Вет. мед. Украӥни. 2006. № 3. С. 39-40.

2. Ковальчук І.Г. Патоморфологічні зміни в собак за гострого перебігу бабезіозу : автореф. дис. ... канд. вет. наук. : 16.00.02. Київ, 2015. 20 с.

3. Пономаренко В.Я., Пономаренко А.Н. Эпизоотическая ситуация по бабезиозу собак в Харьковской области. 3б. матер. IV міжнар. наук.-практ. конф., 14-15 жовтня 1998 р. Київ, 1998. С. 25.

4. Прус М.П., Семенко О. Бабезіоз собак. Мир ветеринарии. 2011. № 1. C. $10-22$.

5. Прус М.П. Бабезіоз собак (епізоотологія, патогенез та заходи боротьби) : автореф. дис. ... докт. вет. наук : 16.00.11. Київ, 2006. 22 с. 
6. Фасоля В.П. Вікова, нозологічна і порідна структура хвороб собак у місті Житомирі. Вісник Білочерків. держ. аграр. ун-ту. 2004. Вип. 28. С. 256-264.

7. Carolien Rutyers Н. Диетотерапия при клинических заболеваниях печени. WALTHAM Focus. Спец. выпуск, 2001. C. 84-92.

8. Irwin P.J., Hutchinson G.H. Clinical and pathological findings of Babesia infections in dogs. Ausiralian Vet. J. 1991. V. 68. № 6. P. 204-209.

9. Meijer A.S., Lamers W.H., Chamuleau R.A. Nitrogen metabolism and ornitine cycle function. Physiol. Rev. 1990. Vol. 7. P. 701-748. 